\title{
Advances in evidence-based information resources for clinical practice
}

The health sciences literature contains the most current and detailed accounts of the testing of various phenomena and innovations related to health promotion and disease control. It also contains the best information available for the management of many healthcare problems. It is voluminous, however, and is often neither well written nor organised for easy clinical application. As a result, its use for solving clinical problems is challenging for even the most persistent and knowledgeable clinicians. Most clinicians indicate that they feel overwhelmed by the literature and don't attempt to use it for solving clinical problems. ${ }^{1}$

Clinicians can use the clinical literature to support clinical decisions in 2 complementary ways: for regular surveillance and for problem oriented searches. Both methods require an appreciation of the many purposes of the clinical literature. They also require a basic understanding of the strengths and weaknesses of studies for providing information that is valid and clinically applicable for questions related to the cause, course, diagnosis, and treatment or prevention of health problems.

In general, the peer reviewed journal literature serves science rather than clinical practice, with its prime function being to facilitate communication from scientist to scientist. ${ }^{2}$ Most of the investigations reported in journals are non-definitive tests of hypotheses and innovations, only a small portion of which may eventually survive testing well enough to warrant routine clinical application.

Reports of definitive studies (scientist-to-clinician communication) are not frequently seen. This situation is cause for both celebration and dismay: celebration because clinicians need to review only a small portion of the literature, and dismay because journals scatter definitive studies among many preliminary investigations. The reader must know and apply critical appraisal skills to identify them.

Clinical review articles are published even less frequently than definitive studies. These reviews constitute clinician-to-clinician communication and the new standards for doing and reporting systematic reviews enhance the likelihood that they will provide valid conclusions based on the best available evidence. ${ }^{3}$ Unfortunately, audits of the methodological rigour of review articles published in journals over the past few years show that many poor quality reviews are still being published in journals. ${ }^{45}$ This problem highlights the need for clinicians to have some knowledge of the principles of critical appraisal.

Many journals also publish case reports and case series. Although at first these seem classifiable as clinician-to-clinician communication, they are perhaps best classified as clinician-toscientist communication. They present ideas that are based on careful observations of unplanned events and that need to be tested in future, planned investigations.

Finally, clinical journals also publish non-clinical scientific articles on a wide range of topics, including news, ethics, parables, and letters. These articles leaven the literature and add enjoyment but at a cost if they distract attention from definitive studies or mislead readers into thinking they bear definitive news for clinical practice when they do not.

Problem oriented searching of the clinical literature The most potent stimuli to learning in clinical practice are the clinical problems we encounter when caring for our patients. To use the clinical literature to help us address these problems, we need to know how to search that literature effectively and efficiently. Recent EBM Notes in Evidence-Based Medicine have described both existing resources and search techniques to help clinicians gain quick, easy access to the evidence needed for specific patient questions ${ }^{6}$ : These include finding the systematic reviews, evidence-based summaries, and original scientist-toclinician reports relevant to patient care. Although there is no single complete solution, existing resources are improving and new ones being developed that we wish to keep readers abreast of (appendix).

\section{A new addition to this journal}

Growth of evidence resources has exploded over the past few years, and it is now becoming a challenge for clinicians to find the most valid and useful evidence-based resources with which to practice. Beginning with this issue, a section titled "Resource Corner" will publish reviews of evidence-based healthcare resources written by frontline clinicians. These resources will include journals (primary and secondary), evidence-based textbooks, computer software, and web sites. Each issue of the journal will contain up to 2 reviews of such products.

Only clinicians without competing interests in the resource under review will be asked to write a review. Our reviewers will be asked to consider specific methodological guides (available to view on http://hiru.mcmaster.ca) when assessing these resource products. In particular, they will consider whether the authors of the resources have identified explicit criteria for determining the validity of the evidence and whether they adhere to these criteria. The reviewers will also provide a "bottom line" recommendation indicating whether and how the resource could be used in practice. We will make the reviews available on the web and will provide electronic links to the reviewed product where possible.

If you would like to review an evidence-based healthcare resource for this journal or would like to nominate a product to be reviewed, please contact us (Dr Sharon Straus, Department of Medicine, Mount Sinai Hospital, Toronto, Ontario M5G 1X5, Canada; Fax + 1416586 8434).

BRIAN HAYNES, MD, PHD

PAUL GLASZIOU, MBBS, PHD SHARON STRAUS, MD 
1 Williamson JW, German PS, Weiss R, et al. Health science information management and continuing education of physicians. Ann Intern Med 1989;110:151-60.

2 Haynes RB. Loose connections between peer-reviewed clinical journals and clinical practice. Ann Intern Med 1990;113:724-8.

3 Oxman $\mathrm{AD}$, Guyatt GH. Guidelines for reading literature reviews. CMAJ 1988;138:697-703.

4 Mulrow CD. The medical review article: state of the science. Ann Intern Med 1987;106:485-8

\section{Appendix}

\section{Selected list of evidence-based healthcare resources \\ TEXTBOOKS}

- Black ER, Bordley DR, Tape TG, et al. Diagnostic Strategies for Common Medical Problems. 2nd edition. Philadelphia: American College of Physicians, 1999

- Clinical Evidence. London: BMJ Publishing Group, 1999. (http://www.bmjpg.com/index.html)

- Dixon RA, Munro JF, Silcocks PB. Evidence Based Medicine:Practical Workbook for Clinical Problem Solving. Boston: ButterworthHeinemann, 1996.

- Friedland DJ, Go AS, Shlipak MG, et al. Evidence-Based Medicine: A Framework for Clinical Practice. Stamford, CT: Appleton \& Lange, 1998.

- Greenhalgh T. How to Read a Paper: The Basics of Evidence Based Medicine. London: BMJ Publishing Group, 1997.

- Haines A, Donald A, editors. Getting Research Findings into Practice. London: BMJ Publishing Group, 1998.

- Lancaster T. Practising Evidence-Based General Practice. Learner's Manual. Oxford: Radcliffe Medical Press, 1999.

- Last JM, ed. A Dictionary of Epidemiology. 3rd edition. New York: Oxford University Press, 1995.

- Levine M, Lexchin J, Pellizzari R. Drugs of Choice:A Formulary for General Practice. Ottawa: Canadian Medical Association, 1998.

- McQuay HJ, Moore RA. An Evidence-based Resource for Pain Relief. Oxford: Oxford University Press, 1998.

- Ridsdale L, editor. Evidence-based Practice in Primary Care. Edinburgh; New York: Churchill Livingstone, 1998.

- Sackett DL, Richardson SR, Rosenberg W, et al. Evidence-Based Medicine: How to Practise and Teach EBM. Edinburgh: Churchill Livingstone, 1997.

- Silagy C, Haines A, editors. Evidence Based Practice in Primary Care. London: BMJ Books, 1998.

- Straus SE, Badenoch D, Richardson WS, et al. Practising Evidence-Based Medicine. Learner's Manual. 3rd edition. Oxford: Radcliffe Medical Press, 1998.

- Straus SE, Sackett DL. Practising Evidence-Based Geriatric Medicine. Learner's Manual. Oxford: Radcliffe Medical Press, 1999.

\section{COMPUTER BASED PRODUCTS}

- Best Evidence. Philadelphia: American College of Physicians. Ordering information http://www.acponline.org/catalog/ electronic/best evidence.htm. Cumulated contents of $A C P$ Journal Club (since 1991) and Evidence-Based Medicine (since 1995) in an annual CD. Also on the internet through Ovid's Evidence-Based Medicine Reviews http://www.ovid.com/ product/ebmr/ebmr.htm

- Cochrane Library. Update Software. Ordering information http://update.cochrane.co.uk/ and http://www.updatesoftware.com/ccweb/cochrane/cdsr.htm Also available
5 McAlister F, Lawson F, Straus SE, et al. The medical review article revisited. Ann Intern Med (In press).

6 Booth A, O'Rourke AJ. Searching for evidence: principles and practice [EBM Note]. Evidence-Based Medicine 1999;4:133-6.

7 McKibbon KA, Richardson WS, Walker-Dilks C. Finding answers to well-built questions [EBM Note]. Evidence-Based Medicine 1999;4:164-7.

through Ovid's Evidence-Based Medicine Reviews http://www.ovid.com/product/ebmr/ebmr.htm

- Drugs of Choice. Canadian Medical Association: Ottawa. Available on 3.5-inch disk for Windows. Ordering information http://www.cma.ca/catalog/252.htm.

- SAM-CD. Scientific American Medicine: New York. Scientific American Medicine on a compact disc and world wide web. Ordering information http://www.samed.com

- UpToDate. UpToDate Inc: Wellesley, MA. Quarterly CD. Ordering information http://www.uptodate.com/

EBM ON THE WEB

A sampling, with links from these to many other sites:

- ACP Journal Club

http://www.acponline.org/journals/acpjc/jcmenu.htm

\section{- Bandolier}

http://www.jr2.ox.ac.uk/Bandolier/band50/b50-8.html

- Best Evidence (to order, in the UK)

http://www.bmjpg.com/data/ebm.htm

- Biomednet (free registration)

http://biomednet.com/

- Canadian Task Force of Preventive Health Care

http://www.ctfphc.org

- Cochrane Library (UK)

http://www.update-software.com/clibhome/clibdemo.htm

- Cochrane Library (San Diego)

http://www.updateusa.com/clibpw/clibdemo.htm

- Community of Science (user ID and password required)

http://muscat.gdb.org/repos/medl

- Critical Care Critically Appraised Topics

http://ahsn.lhsc.on.ca

- EBM Journal (Evidence-Based Medicine en français)

http://www.ebm-journal.presse.fr/ebmjournal/

\section{- Evidence-Based Medicine}

http://www.bmjpg.com/data/ebm.htm

- Evidence-Based Mental Health

http://www.ebmh-online.com

- HealthGate (registration required)

http://www.healthgate.com

- HealthWorld

http://www.healthworld.com/Library/search/medline.htm

- Institute for Clinical Evaluative Sciences Informed newsletter

http://www.ices.on.ca/docs/informed.htm 
- Journal of Family Practice Patient-Oriented Evidence that Matters (POEMS)

http://jfp.msu.edu/jclub/jc0496b.htm

- Knowledge Finder (must be registered user)

http://www.kfinder.com/

- Links to journal web sites and fulltext journal articles:

http://pslgroup.com/dg/medjournals.htm

http://www.nthames-health.tpmde.ac.uk/connect/journals.htm

- McMaster University Health Information Research Unit

http://hiru.mcmaster.ca

- Miner Library in Rochester

http://www.urmc.rochester.edu/Miner/Links/ebmlinks.html

- National Guideline Clearinghouse

http://www.guideline.gov

- Neurosurgery

http://www.brown.edu/Departments/Neurosurgery/EJC/

journ.html

- NNT calculators and tools

http://www.shef.ac.uk/ scharr/ir/nnt.html

- Oxford Centre for Evidence-Based Medicine

http://cebm.jr2.ox.ac.uk

- PalmTop software for EBM

http://www3.mtco.com/glwoods/Default.htm

- Pediatric Critical Care Medicine

http://pedsccm.wustl.edu/EBJournal_club.html

- ScHARR (links to most other EBM sites)

http://www.shef.ac.uk/uni/academic/R-Zscharr/ir/netting.html
- Society for General Internal Medicine Medical SmartSearch http://smartsearch.uthscsa.edu/cgi-bin/smartsearch.exe

- University of York/NHS Centre for Reviews and Dissemination (including links to Effective Health Care and Effectiveness Matters)

http://www.york.ac.uk/inst/crd/dissem.htm

- Web-based Literature Search Hedges:

http://www.mssm.edu/library/ebm.ebmhedges.htm

How to cite material from Evidence-Based Medicine

Citation of material from the Notebook

Milne R, Hicks N. Evidence-based purchasing [EBM Note]. Evidence-Based Medicine 1996 May-Jun;1:101-2.

Citation for material taken from a structured abstract, written without attribution by a staff member

Antihypertensive drugs decrease mortality, coronary events, and stroke in elderly persons [abstract]. Evidence-Based Medicine 1996 May-Jun;4:105. Abstract of: Pearce KA, Furberg $\mathrm{CD}$, Rushing J. Does antihypertensive treatment of the elderly prevent cardiovascular events or prolong life? A meta-analysis of hypertension treatment trials. Arch Fam Med 1995;4:943-50.

Citation for material taken from a commentary to an article

Olds D. Commentary on "Home visiting programmes reduce childhood injury." Evidence-Based Medicine 1996 MayJun;4:112. Comment on: Roberts I, Kramer MS, Suissa S. Does home visiting prevent childhood injury? A systematic review of randomised controlled trials. BMJ 1996;312:29-33.

\section{Journals reviewed for this issue*}

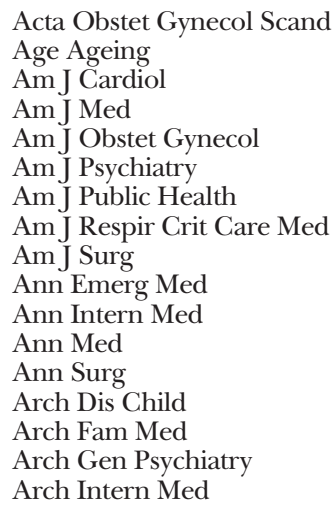

Arch Neurol

Arch Pediatr Adolesc Med

Arch Surg

Arthritis Rheum

BMJ

Br J Gen Pract

Br J Obstet Gynaecol

Br J Psychiatry

Br J Surg

CMAJ

Chest

Circulation

Clin Invest Med

Clin Pediatr

Cochrane Library

Crit Care Med
Diabetes Care

Fertil Steril

Gastroenterology

Gut

Heart

Hypertension

JAMA

J Am Board Fam Pract

J Am Coll Cardiol

J Am Coll Surg

J Am Geriatr Soc

J Clin Epidemiol

J Fam Pract

J Gen Intern Med

J Infect Dis

J Intern Med
J Neurol Neurosurg Psychiatry

J Pediatr

J Vasc Surg

Lancet

Med Care

Med J Aust

N Engl J Med

Neurology

Obstet Gynecol

Pain

Pediatrics

Rheumatology

Spine

Stroke

Surgery

Thorax

*Approximately 60 additional journals are reviewed. This list is available on request. 